\title{
Note on two species of Cucumaria from Plymouth, hitherto confused as C. Montagui (Fleming) : C. Normani, n. sp., and C. saxicola, Brady and Robertson.
}

\author{
By
}

S. Pace.

Pending the publication, in a paper now in preparation, of an account of the Holothuria of the Plymouth district, and an attempt at a revision of the European species of that group, it has appeared advisable to publish the following short note*, with the view of removing one of the most prolific of those sources of error with which the literary history of the Holothuria has come to be burdened.

Holothuria Montagui, Fleming, affords a remarkable instance of how much confusion may gather around a specific name; the species was itself founded on a misconception, and almost every author who has since made use of Fleming's name, or who has attempted to disentangle its synonymy, has but made matters rather more involved. It is not my intention to discuss the synonymy of $C$. Montagui at all fully in the present paper, as it will be more convenient to do this subsequently, when dealing with other species, and only so much of the history of the name will now be mentioned as is essential to the immediate purpose of the present note.

In 1808 Montagu (4) described and figured as "Holothuria Pentactes, var.," a species of Cucumaria which he had found on the south coast of Devonshire. This species, from Montagu's excellent description, must certainly have been one of the two forming the subject of this paper; and which has, among other names, been known as C. Montagui, Fleming. Now, whatever C. Montagui really may be, it certainly is not conspecific with Montagu's supposed variety of $C$. pentactes. Of course, it was undoubtedly Fleming's intention to honour Montagu by bestowing his name upon the species discovered by that naturalist; but, unfortunately, the description (2) of C. Montagui is based upon specimens of another species collected in the Firth of Forth. Fleming makes reference under the name Montagui to Montagu's description

* My thanks are due to Dr. E. J. Allen, Director of the Plymouth Laboratory, for allowing me to devote the necessary time to this research; to Prof. F. J. Bell for granting me facilities for working at the collections under his care at the British Museum ; and to Dr. A. M. Norman for much friendly criticism. 
of the Devonshire Cucumarian, but Montagu's actual form is probably the one that is described as Holothuria pentactes in the History of British Animals.

Fleming's name appears to have dropped into almost complete disuse until revived by Dr. A. M. Norman (5). Norman, however, overlooked the fact that Fleming was not dealing with the same species as Montagu; and in addition, he has failed to realise that there are two species of Cucumaria of somewhat similar outward appearance living upon the South Devon coast. Norman's Cucumaria Montagui is, in fact, a complex, and it is mainly as the result of this that subsequent authors have experienced so much difficulty in reconciling their ideas as to the identity of C.Montagui.

Before proceeding further, it will, perhaps, be most convenient to say something regarding the characters and habits of the two Cucumarians in question, and to call attention to the more important points of difference between them.

During life it is an easy matter to separate the two forms; and from quite an early date in the history of the Plymouth Laboratory they have there been recognised as distinct species. At Plymouth, for some years past, these species have been recorded and distributed as " $\mathrm{C}$. pentactes," and "C.Planci," the one known by the latter name being the one figured by Montagu. However, neither of these names can be retained. Linnæus' Holothuria pentactes is now generally regarded as being an indeterminate* species; and, whether Brandt's name Planci be eligible for the common Mediterranean species or not, it certainly cannot be applied to the very different species from Plymouth. For the moment, it will perhaps simplify matters if we refer to Montagu's "Holothuria pentactes, var.," as Cucumaria sp. 1 and to the second Plymouth form as Cucumaria sp. 2.

Both of these species of Cucumaria, sp. 1 and sp. 2, are fairly common in the neighbourhood of Plymouth Sound, being found under stones and in crevices on rocky ground from low-water mark down to a depth of a few fathoms. Sp. 2 is perhaps the more frequently met with, and it appears, also, to live in somewhat deeper water.

There are no very great points of difference in the outward form of the two species, which are also of much the same size; but $s p .1$ is rather shorter and of less even calibre than sp. 2, and it has the posterior extremity more tapering. The podia in sp. 1 are numerous, appearing as though disposed in two parallel rows in each ambulacrum;

* Absolutely no useful purpose is served by guessing as to what an author had before him when founding a species. Unless, in the case of an insufficiently described species, the type-specimen is available, it is far better to entirely discard the name in question rather than to accept the interpretation of a subsequent author. The latter course is a fruitful source of error, for it is seldom possible to say definitely which later writer is the one to be followed. 
while in sp. 2 they are so few as to appear arranged in a single zigzag series; also, in the latter species, the podia are less completely retractile. The arborescent tentacles are very similar in both forms. The general body colour of $s p .1$ is a dirty, brownish white; while in sp. 2 it is a pure milk white, excepting the tips of the podia, which are yellowish. Both species are absolutely without maculation. In sp. 1 the neck and the bases of the tentacles are uniformly tinged a rich purple-brown colour, with more or fewer scattered pigment granules of an even darker colour. On the other hand, in sp. 2 these parts are typically pale, although generally they are more or less dusted with dark-coloured pigment granules, and sometimes, indeed, to such an extent as to render the neck region quite dark; but in such a case the dark pigmentation is never diffuse, as it invariably is in $s p .1$. The interspaces between the anal papilloe are darkly pigmented in sp. 1, and in sp. 2 the interior of the anal orifice is reddish or orange coloured. A great difference is noticeable in the texture of the surface. In sp. 1 the test, being densely crowded with spicules, is very tough and coriaceous, and its surface is much wrinkled, while in $s p .2$ the surface of the body is extremely smooth and delicate, marked only with transverse strixe due to the encircling fibres of the superficial muscle layer.

The spicular deposits, which are much more numerous in $s p .1$ than they are in $s p .2$, show considerable and characteristic differences. The general body spicule in $s p .1$ is typically lozenge-shaped, perforated with four large foramina, and always bearing about twelve very prominent nodules: in $s p$. 2 the corresponding spicule is invariably absolutely devoid of nodulation, and an additional foramen is typically developed at each end of the long axis of the spicule, thus doing away with the simple lozenge shape. The upper body spicules of the two forms offer even greater diversity of structure: while in $s p .1$ they are numerous and campanulate in form, in $s p .2$ they are quite typical 'tables,' and, being few in number, are easily overlooked. The lateral deposits of the podia in $s p .1$ have their foramina typically in a single series, while in $s p .2$ they are arranged in two or more parallel rows, or with a group of three or four small foramina at each end of the spicule.

Returning now to Dr. Norman's paper on Cucumaria Montagui, Norman first briefly describes the external features of three spirit specimens, which he terms specimens 'A,' 'B,' and 'C,' and which with others had been collected for him by a local naturalist at Polperro, a few miles west of Plymouth. He then goes on to give a very full and remarkably lucid account of the spicules of each of these specimens individually. Specimen 'A' is certainly an example of what we have termed Cucumaria, sp. 1: the general body spicules, the campanulate deposits, and those of the podia and tentacles being well described. 
Regarding his specimen 'B,' Norman says: "Body-spicule like that of A, but only a spicule here and there showing any nodulous growth, the vast majority presenting a perfectly smooth surface; nor are they so universally confined to the number of four foramina, the spicules often having an additional foramen at each end (i.e. four in a direct central longitudinal line). . . . No bell-shaped spicules have been found in this specimen, though they have been thoroughly sought for. Pedicels with lateral spicules, some just as in $\mathrm{A}$, but here more generally with about three small foramina at each end." With reference to his specimen 'C,' Norman writes as follows: "Body-spicule exactly as in B, but here I could not find a single one that was nodulous, and no bell-shaped spicules. Pedicel-spicules as in B."

From the above quotations it will be seen that while Norman is thus describing in his specimens ' $\mathrm{B}$ ' and ' $\mathrm{C}$ ' the body-spicule of a Cucumarian which is evidently the same as my Cucumaria, sp. 2, he regards this spicule, by reason of the presence of a few scattered nodulous spicules in one of the preparations he examined, as a mere modification of that type which he had met with in his specimen ' $A$,' and which is characteristic of my Cucumaria, sp. 1. There can, however, be no doubt as to the absolute distinctness of the two spicule types, and the explanation of their apparent coexistence in Norman's specimen ' B' is probably a very simple one indeed; namely, that a few spicules of the first species were adhering to the surface of specimen 'B.' It must be remembered that all Dr. Norman's specimens had been preserved in the same bottle *; and I have been able to prove experimentally that under such condition it is a very easy matter for spicules from one individual to become transferred to the mucus, enveloping the body of another specimen; in fact, I was myself very nearly misled in this manner. It is also to be noted that Norman was unable to make out the upper body deposits, which, as already remarked, are not very easily seen in $s p$. 2, in either of his specimens ' $\mathrm{B}$ ' or ' $\mathrm{C}$ '; had he observed these he would have seen immediately that he was dealing with a species different to that of his specimen 'A.'

Misled by the apparently enormous variability of the spicules of the specimens examined by him, Norman was induced to unite with C. Montagui a couple of other species, Cucumaria Lefevrei, Barrois, and Semperia Drumondi, Hérouard, which are probably distinct, and also to suggest the possible identity of still others: a suggestion which subsequent authors have not been slow to follow. $†$

* I have been able to examine the original bottle, which is now in the British Museum, and $I$ can affirm that it contains both the species referred to in this paper.

† Kœhler (3) considers that Norman erred in uniting Hérouard's Colochirus Lefevrei with $H$. Montagui; but the evidence he adduces in support of this view is rather strange, and shows that he cannot have read Norman's paper at all carefully, for he instances the spectacle shape of the spicules of Norman's Cucumaria Montagui, and their invariable want of nodulation, as points of difference between it and C. Lefevrei! 
Journ.Mar. Biol. Assoc.Vol.VII

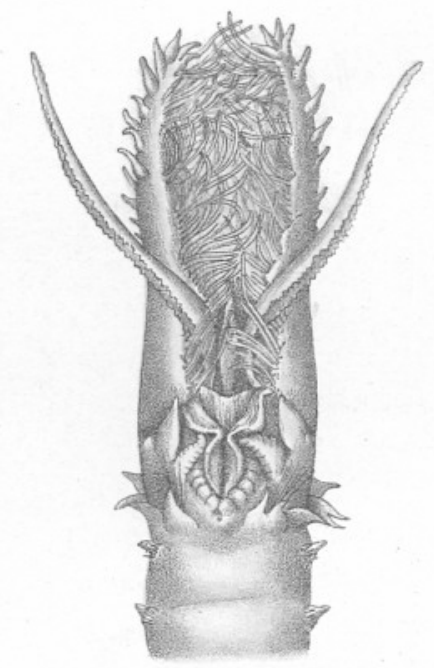

3

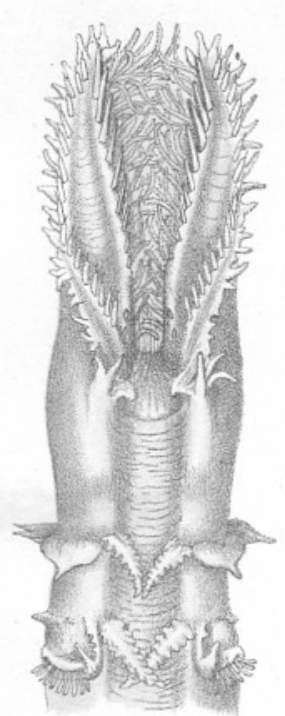

4

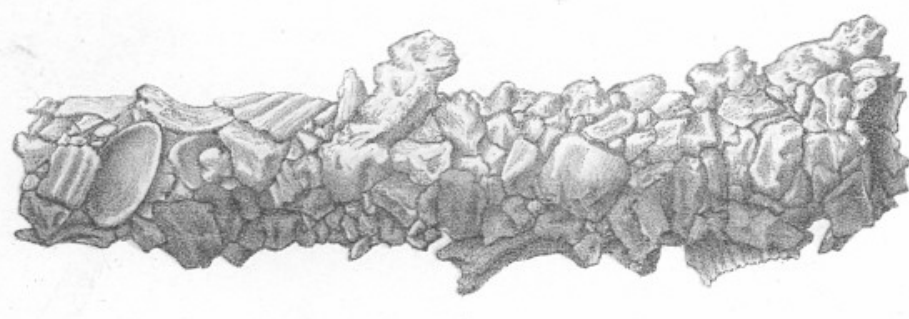

5

E.W. Sexton del.

Coming now to the question of the nomenclature of the two species of Cucumaria, which for convenience have hitherto in this paper been referred to merely as species ' 1 ' and ' 2 .' It is unfortunate that the name Montagui cannot be retained for sp. 1 , more especially as this form would in consequence appear to be as yet without a legitimate name; to meet this deficiency I would propose that the species be called Cucumaria Normani. Regarding the second species, this would appear to be the same as a form described more than thirty years since by Brady and Robertson (1) from the West of Ireland as Cucumaria saxicola, but which has since remained a 'doubtful' species.

Cucumaria Normani, n. sp.

1808: "Holothuria Pentactes, var.": G. Montagu, Trans. Linn. Soc., vol. ix. p. 112 , pl. vii., fig. 4 .

1893, Dec.: "Cucumaria Montagui (Fleming)": A. M. Norman, Ann. Mag. Nat. Hist., ser. 6, vol. xii. p. 469 [excl. specimens 'B' and ' $\mathrm{C}$ ' and synonymy].

Diagnosis.-Body of uniform dirty white or brownish colour, neck and bases of tentacles darkly pigmented, the pigment diffused. Test very coriaceous, densely crowded with deposits. Body-spicule typically lozenge-shaped, nodulous, and with four symmetrically disposed perforations. The foramina on the long axis of the spicule smaller and nearly circular, those of the short axis larger and elliptical in outline, the long axes of the foramina parallel to that of the spicule. Upper body-spicule campanulate, typically with four short arms which, arising from the ends of a short cross-bar, curve down to, and are inserted on a nodulous circular rim.

Habitat.-Plymouth, on rocky ground, L.W.-10 fms. The typespecimen from Blackstone Rocks, Wembury Bay.

Trpe-Specimen.-Has been acquired by the British Museum.

\section{REFERENCES.}

1. Brady, G. S., and Robertson, D.-Descriptions of two new Species of British Holothuroidea. Proc. Zool. Soc., vol. 1871, pp. 690-2, pls. 1xxi.-lxxii.

2. Fleming, John.-A History of British Animals, exhibiting the Descriptive Characters and Systematic Arrangement. . . Edinburgh, 1828.

3. Kœhler, R.-Sur la Détermination et la Synonymie de quelques Holothuries. Bull. Sci. France Belg., ser. 4, vol. iv, pp. 353-66 ; Sept. 1895.

4. Montagu, George.-Description of several Marine Animals found on the South Coast of Devonshire. Trans. Linn. Soc., vol. ix. pp. 81-114; 1808.

5. Norman, A. M.--Cucumaria Montagui (Fleming) and its Synonymy. Ann. Mag. Nat. Hist., ser. 6, vol. xii. pp. 469-73 ; Dec. 1893. 